\title{
RESPONSE OF COWPEA LINES TO INOCULATION WITH FOUR SEED TRANSMITTED VIRUSES OF COWPEA
}

M. A. ITTAH, I. FAWOLE, S. A. SHOYINKA AND J. D'A. HUGHES

(Received 1, December 2008; Revision Accepted 2, November 2008)

\begin{abstract}
This study evaluated the performance cowpea genotypes in the field in Ibadan, Nigeria for response to infection induced by four seed transmitted viruses of cowpea. The experiment was laid out in split plot design with three replicates. Cowpea mottle virus genus Carmovirus (CMeV) produced infection in 14 of the 15 lines, Bean common mosaic virus genus Potyvirus - blackeye cowpea strain (BCMV - BIC) in 12, Cowpea aphid-borne mosaic virus genus Potyvirus (CABMV) in 11 and Southern bean mosaic virus genus Sobemovirus (SBMV) in 6. BCMV - BIC significantly reduced $(p<0.05)$ the grain yield, number of pods per plant, number of seeds per plant and shoot length than $\mathrm{CMeV}$, and $\mathrm{CMeV}$ reduced the same traits than CABMV and SBMV. Percentage reduction in the grain yield induced by BCMV - BIC infection ranged from $62.6 \%$ in CP-VAR8 to $87.7 \%$ in IT86D-371, CMeV from $49.9 \%$ in IT90K-284-2 to $91.4 \%$ in IT82D-889, CABMV from $20.2 \%$ to $87 \%$ and SBMV from $31.8 \%$ to $69.2 \%$. Similar trend was observed in the reduction of the number of pods per plant, plant height and number of seeds per pod. The four viruses did not affect the number of days from planting to $50 \%$ flowering and the number of days from planting to maturity. IT90K-284-2, IT82D-889, TVu 11426 and IT86D-880 were resistant to infection caused by BCMV - BIC, CABMV and SBMV but were tolerant to CMeV infections. CP-VAR8 was resistant to infections induced by CMeV and SBMV. The cultivation of these lines should be encouraged in the areas where the viruses are endemic.
\end{abstract}

KEY WORDS: Cowpea, Vigna species, Virus infections, Cowpea Diseases, Seed Transmitted Viruses

\section{INTRODUCTION}

Cowpea (Vigna unguiculata $(L)$ Walp) is a tropical legume, which provides affordable protein for humans and animals in Sub-Saharan Africa, Asia and Latin America (Mishra et al., 1985; Singh and N'tare, 1985; Watt et al., 1985; Bashir and Hampton 1993; Tarawali et al., 2002). Cowpea serves also as cover crop, in soil nitrogen fixation and in the control of erosion and weeds (Hutchinson and McGiffen, 2000). FAO (2000) estimated that 3.3 million tonnes of dry cowpea grains were produced from 9.8 million hectare of land worldwide. More than $60 \%$ of the world cowpea is produced by Nigeria and Niger Republic (Quin, 1997).

Seeing the value of the crop and in support that its production should be increased, Coulibaly and Lowenberg - DeBoer (2002) stated that cowpea has the potential to contribute to food security and reduce poverty in West Africa, provided that both socioeconomic and biological constraints are adequately tackled. Such socio - economic and biological constraints include poor management of resources, poor application of appropriate cultural technologies, infestation by weeds and insect pests, and infection by diseases (Jackai and Adalla, 1997; Quin, 1997).

Plant diseases; especially those transmitted by the seeds, play very important role in loss of valuable food crop throughout the world (De Wolf and Isard, 2007). Virus infections are the cause of numerous plant disease syndromes that are generally characterized by
(Culver and Padmanabhan 2007). Seed transmitted viruses are important pathogens because the pathogens lodge in seed tissues such as embryo and disease symptoms may manifest in seedlings grown from the seeds (Stace - Smith and Hamilton, 1988). A few infected seedlings may be the source of epidemic infections in the field if vectors (aphids, beetles, etc.) convey the pathogens to healthy plants during feeding. Seed transmitted viruses hiding in seeds in storage retain their ability to cause infection for many years even after the seeds had lost viability (Bennett, 1969).

Seven of the viruses infecting cowpea are seed transmitted and are found in all cowpea growing areas (Hampton, et al., 1997). For example, Bean common mosaic virus genus Potyvirus - blackeye cowpea strain (BCMV - BIC) was reported in Brazil, India, Kenya, Nigeria, and other parts of the world (Mali, et al., 1983; Taiwo and Shoyinka 1988; Shoyinka et al., 1997; Boxtel et al., 2000). Infections caused by seed- borne viruses also reduce seed quality and potential yield of crops. Phatak (1974) observed that cowpea ringspot virus infection distorted cowpea pods and cowpea aphid borne mosaic virus genus Potyvirus (CABMV) infection reduced yield in cowpea by between 48 to $87 \%$ (Kaiser and Mossahebi, 1975).

Considering the damage that cowpea seed transmitted viruses can bring about in susceptible

M. A. ITTAH, Department of Crop Science, Faculty of Agric

I. FAWOLE, Department of Crop Protection and Environmer 18

S. A. Shoyinka, Institute of Agricultural Research and Training, Obafemi Awolowo University, Ile Ife, Nigeria

J. d'A. Hughes, Plant Health Management Division, International Institute of Tropical Agriculture, Ibadan, Nigeria

uIe Illuuclivil uI uisease syilipivills suull as developmental abnormalities, chlorosis and necrosis niluvileuye vvill ellavie lallilels lliane illuillieu judgement when choosing planting materials in virus 
endemic regions. Also, the information on resistance and susceptibility status of genotypes can be used in genetic studies and in breeding elite cowpea genotypes.

Studies of this sort should be routinely conducted to identify possible variation in the interaction between virus strains and cowpea genotypes. The objective of this study was to evaluate the effect of four seed-borne viruses on the performance of some cowpea lines.

\section{Materials and Methods}

Fifteen cowpea genotypes were chosen from a screen - house study reported by Ittah (2004) and evaluated in the field for their responses to infection caused by four seed-borne viruses. Isolates of Bean common mosaic virus genus Potyvirus - blackeye cowpea strain (BCMV - BIC), Cowpea aphid-borne mosaic virus genus Potyvirus (CABMV), Cowpea mottle virus genus Carmovirus (CMeV) and Southern bean mosaic virus genus Sobemovirus (SBMV) were obtained from the Virology unit of the International Institute of Tropical Agriculture (IITA), Ibadan, Nigeria and maintained in life plant (Ife brown) culture in an insect free screen - house in the unit.

The cowpea genotypes were Ife Brown, IT82D-716, IT82D-889, IT84S-2246-4, IT86D-371, IT86D-880, IT96D-774, TVu 12349, CP-VAR8, IT83D-442, IT90K284-2, TVu 66, TVu 11426, TVu 1190, and TVu 13686. These genotypes were chosen based on their infection status, to determine their responses under field conditions. The field was laid out in a split - plot design with three replicates. The four viruses and control were the 5 main-plot treatments and the cowpea genotypes were the sub-plot treatments. Plot size was $486.75 \mathrm{~m}^{2}$, a ridge (sub-plot) was $10 \times 1 \mathrm{~m}$, plant spacing was $60 \mathrm{~cm}$, inter-ridge spacing was $100 \mathrm{~cm}$ and inter-block spacing was $2.0 \mathrm{~m}$. Weeds were removed first by slashing and ploughing, then with the pre - emergence herbicide; Gramoxone, which was applied with knapsack sprayer after seeds were planted at the rate of 5 litres per hectare. Subsequent weeding was done manually and Karate was sprayed fortnightly to control insects and prevent cross contamination of viruses through vectors.

Cowpea plants were mechanically inoculated with inoculum of each virus. Inoculum was prepared by picking young virus infected leaves $(3-5)$ from Ife brown cowpea plants maintained in the screenhouse and ground in ice-cooled mortars and pestles in inoculation buffer. The buffer was made up of $1 \mathrm{~g}$ of dibasic potassium phosphate $\left(\mathrm{K}_{2} \mathrm{HPO}_{4}\right), 1 \mathrm{~g}$ monobasic potassium phosphate $\left(\mathrm{KH}_{2} \mathrm{PO}_{4}\right), 0.1 \mathrm{~g}$ of sodium sulphite $\left(\mathrm{Na}_{2} \mathrm{SO}_{3}\right)$ in $100 \mathrm{ml}$ distilled water at $\mathrm{pH}$ 7.5. It was stored in the refrigerator until required (Walkey, 1985). Carborundum powder (600 mesh) was sprinkled on the leaf surface at the emergence of the first trifoliate leaf (5 - 8 days after planting) before rubbing the inoculum into the lines. The fingers were protected with rubber gloves to prevent cross infection. Excess inoculum was rinsed off with distilled water. Plants in control plots were not inoculated.

Virus expressions on the cowpea plants were confirmed with Protein-A sandwich enzyme linked immunosorbent assay (PAS - ELISA), a serological test (Hughes and Thomas, 1988). Polyclonal antisera to the viruses were obtained from Virology Unit of IITA, Ibadan. Five randomly selected plants from plots without symptoms were similarly tested to find out if there were viruses latently hiding in the leaf tissues. Plants in the control plots were tested regularly to ensure that there were no cross infections. Plants with other viruses or contaminated with non-specified viruses were removed. The disease symptom expression was visually scored using a 5-point scale (Thottappilly, et al., 1994) as follows;

$1=\quad$ Highly resistant (disease symptoms were not observed on the leaves and ELISA results were negative).

$2=\quad$ Resistant (less than $20 \%$ of the leaves on each plant expressed symptoms of the specified virus or ELISA results of symptomless plants were positive).

$3=\quad$ Moderately resistant (symptoms of the specified virus appeared on $21-40 \%$ of the leaves).

$4=$ Susceptible (symptoms of the specified virus appeared on $41-60 \%$ of the leaves).

$5=\quad$ Highly susceptible (symptoms of the specified virus appeared on more than $60 \%$ of the leaves).

Means were compared using Least Square Means (LSMeans) and associated standard errors, using pairwise differences (pdiff) of means option in statistical analysis system (SAS) (SAS Institute, 1995). The disease severity means were logarithmically transformed because data were taken by count, which would not fit into the law of normality (Gomez and Gomez, 1984).

\section{RESULTS}

\section{Disease expression and Growth Manifestations}

Table 1 shows cowpea lines response to infection, and severity and incidence of infection induced by the seed transmitted viruses on the cowpea lines. All the cowpea genotypes expressed symptoms of one virus or the other. The severity of BCMV - BIC infection ranged from 1.0 in IT90K-284-2 to 4.8 in IT96D-774, that of CABMV from 1.0 in IT86D-880 and IT90K-284-2 to 4.3 in IT96D774, CMeV from 1.2 in CP-VAR8 to 4.7 in IT82D-716 and IT84S-2246-4, and SBMV from 1.0 in 8 cowpea lines to 4.2 in IT96D-774 and TVu 66. The incidence of infection measured the spread of the diseases in the plots; all the plants in the Ife brown, IT82D-716, IT84S2246-4, IT96D-774, TVu 1190 and TVu 13686 plots inoculated with the BMCV - BIC virus were infected, all the plants in IT84S-2246-4 plot inoculated with CABMV were infected. Similarly, all of the plants in 8 plots (Ife brown, IT82D-716, IT82D-889, IT84S-2246-4, IT86D880, IT96D774, TVu 66 and TVu 13686) inoculated with the $\mathrm{CMeV}$ virus were diseased, however, the trend that all the plants in the plot expressed symptoms of infection of the virus was not recorded in the plots where SBMV was inoculated. The highest incidence of infection in SBMV inoculated plots was $60 \%$ of the plants in IT84S2246-4, IT96D-774 and TVu 66.

IT86D-880 and IT90K-284-2 were highly resistant to BCMV - BIC, CABMV and SBMV. IT86D-371, IT86D880 and $T V u 11426$ were tolerant to the infections caused by all the four viruses because the severity of infection scored between 1.0 and 3.5, and incidence of infection was less than $40 \%$. Similarly, IT82D-889, IT90K-284-2, IT83D-442 and TVu 12349 were tolerant to infection induced by three of the four viruses (BCMV - 
BIC, CABMV and SBMV). CP-VAR8 was the only line that was highly resistant to the infections caused by CMeV.

\section{Days to $\mathbf{5 0} \%$ flowering and days to maturity}

Infection caused by the seed transmitted viruses did not significantly $(p<0.05)$ influence the number of days from planting to when $50 \%$ of the plants on the plots flowered (Table 3) and the number of days from planting to maturity in any cowpea lines (Table 4).

\section{Plant height/length of shoot}

The mean length of shoot of the cowpea lines at maturity under the 5 virus treatment is shown in Table 4. The length of shoot of the uninoculated Ife brown variety was $109.6 \mathrm{~cm}$, the mean length was significantly longer $(p<0.05)$ than the Ife brown plants infected by BCMV BIC $(38.9 \mathrm{~cm}), \mathrm{CMeV}(73.2 \mathrm{~cm})$ and SBMV $(73.7 \mathrm{~cm})$. The mean length of TVu 66 variety in the control plot was $70.8 \mathrm{~cm}$; it was also, significantly longer $(p<0.05)$ than the same variety inoculated with all the viruses except SBMV. Similar trend was observed in the other susceptible varieties. BCMV - BIC significantly reduced the length of shoot in 12 genotypes, the percentage reduction ranged from $19.6 \%$ to $64.5 \%$; $\mathrm{CMeV}$ significantly reduced the length in 9 lines between $11.4 \%$ in IT90K-284-2 and $41.8 \%$ in TVu 13686; CABMV in 3 and SBMV in 5 lines $(p<0.05)$. There were no significant differences in the length of shoot in three lines (IT82D-889, IT86D-880 and IT90K-284-2) infected with any of the four viruses $(p<0.05)$; these genotypes were the highly resistant genotypes, whereas, highly susceptible genotypes infected by $\mathrm{CMeV}$ and BCMV - BIC were stunted.

\section{Number of pods per plant}

Table 5 compares the number of pods per plant in the cowpea lines infected with the seed transmitted viruses. In Ife brown line, the control plot had an average of 27.1 pods per plant whereas the plots infected with the viruses had significantly $(p<0.05)$ less number of pods per plant, the trend was observed in the other susceptible lines; IT82D-716, IT84S-2246-4, IT96D-774 and TVu 66. Infection by BCMV - BIC significantly $(p<0.05)$ reduced the number of pods per plant in 12 lines. The most severely affected lines were Ife Brown (69.1\%), TVu 1190 (66.4\%), IT84S-2246-4 $(58.7 \%)$ and IT96D-774 (56.2\%). CMeV significantly reduced the number of pods per plant in 14 lines, percentage reduction in the number of pods per plant ranged from $16.5 \%$ in IT82D-889 to $57.4 \%$ in IT84S2246-4. CABMV infection significantly reduced the number of pods per plant in 9 lines, percentage reduction ranged from 10.1 to $33 \%$ while SBMV decreased the number of pods per plant in 6 lines between 11.8 and $30.3 \%(p<0.05)$.

BCMV - BIC, CABMV and SBMV infections did not significantly reduce the number of pods per plant in four lines; IT82D-889, IT86D-880, IT90K-284-2 and TVu 11426. The highly resistant and resistant lines experienced no significant reduction in the number of pods, while susceptible and highly susceptible lines suffered the highest reduction in the number of pods per plant.

\section{Number of seeds per pod}

.The effects of the infection induced by the seed transmitted viruses on the number of seeds per pod are shown in Table 6 . Infection by BCMV - BIC significantly reduced number of seeds per pod $(p<0.05)$ in 9 lines (Ife brown, IT82D-716, IT82D-889, IT84S2246-4, IT96D774, CP-VAR8, TVu 66 TVu 1190 and TVu 13686); the percentage reduction ranged from $9.1 \%$ in TVu 12349 to $46.2 \%$ in Ife Brown. CMeV infection significantly reduced number of seeds per pod in 11 cowpea lines, between $11.7 \%$ in IT82D-889 to $35.9 \%$ in IT96D-774 ( $<<0.05)$, CABMV in 7 lines between $9.0 \%$ and $23.1 \%$, while SBMV reduced the number of seeds per pod in four lines ranging from $8.5 \%$ in TVu 1190 to $16.8 \%$ in Ife Brown $(p<0.05)$. Susceptible and highly susceptible genotypes were the most severely affected by each of the viruses, and they had the highest percentage reduction in the number of seeds per pod.

\section{Grain yield per hectare}

Table 7 shows the grain yield (in $\mathrm{Kg} / \mathrm{Ha}$ ) of the cowpea lines after infection of the four seed transmitted viruses and the uninoculated plot in the field. The average yield of Ife brown variety in the control plot was $1058.4 \mathrm{Kg} / \mathrm{Ha}$; this yield was significantly higher $(p<$ 0.05 ) than the yield observed after the infection of BCMV - BIC (245.5 Kg/Ha), CABMV (260.6 Kg/Ha), $\mathrm{CMeV}(224.8 \mathrm{Kg} / \mathrm{Ha})$ and SBMV $(721.6 \mathrm{Kg} / \mathrm{Ha})$. The trend was the same in all the susceptible lines infected with the viruses; $\mathrm{CMeV}$ infections caused significant reduction $(p<0.05)$ of the grain yield of 14 cowpea lines, the percentage decrease ranged from $49.9 \%$ in IT90K284-2 to $91.4 \%$ in IT82D-889, and BCMV - BIC in 12 lines ranging from $62.6 \%$ in CP-VAR8 to $87.7 \%$ in IT86D-371 ( $p<0.05)$. CABMV also caused significant reduction $(p<0.05)$ in the grain yield of 10 lines; from $20.2 \%$ in TVu 13686 to $87 \%$ in IT86D-371 and SBMV in 8 lines from $31.8 \%$ to $69.2 \%$. Very severely infected genotypes had the highest reductions in grain yield, while the highly resistant genotypes were not infected despite that they were inoculated with the viruses; their grain yield were not significantly different from the plants that were not inoculated (i.e. control).

Table 1. Response to infection, Infection severity and incidence of infection of four seed transmitted viruses on cowpea lines at $90 \%$ maturity

\begin{tabular}{|c|c|c|c|c|c|c|c|c|c|c|c|c|}
\hline \multirow[t]{2}{*}{ Lines } & \multicolumn{3}{|c|}{ BCMV-BIC } & \multicolumn{3}{|c|}{ CABMV } & \multicolumn{3}{|c|}{$\mathrm{CMeV}$} & \multicolumn{3}{|c|}{ SBMV } \\
\hline & RES & SEV & INC & RES & SEV & INC & RES & SEV & INC & RES & SEV & INC \\
\hline
\end{tabular}




\begin{tabular}{lllllllllllll} 
Ife Brown & HS & 4.2 & 100 & $\mathrm{~S}$ & 3.8 & 90 & $\mathrm{HS}$ & 4.4 & 100 & $\mathrm{MR}$ & 2.7 & 40 \\
IT82D-716 & $\mathrm{S}$ & 3.4 & 100 & $\mathrm{~S}$ & 3.6 & 60 & $\mathrm{HS}$ & 4.7 & 100 & $\mathrm{MR}$ & 2.6 & 40 \\
IT82D-889 & $\mathrm{R}$ & 1.8 & 20 & $\mathrm{HR}$ & 1.2 & 0 & $\mathrm{~S}$ & 3.5 & 100 & $\mathrm{HR}$ & 1.0 & 0 \\
IT84S-2246-4 & $\mathrm{HS}$ & 4.8 & 100 & $\mathrm{~S}$ & 3.6 & 100 & $\mathrm{HS}$ & 4.7 & 100 & $\mathrm{~S}$ & 3.6 & 60 \\
IT86D-371 & $\mathrm{MR}$ & 2.3 & 80 & $\mathrm{R}$ & 1.4 & 40 & $\mathrm{MR}$ & 2.6 & 60 & $\mathrm{HR}$ & 1.0 & 0 \\
IT86D-880 & $\mathrm{HR}$ & 1.2 & 0 & $\mathrm{HR}$ & 1.0 & 0 & $\mathrm{MR}$ & 3.0 & 60 & $\mathrm{HR}$ & 1.0 & 0 \\
IT96D-774 & $\mathrm{HS}$ & 4.8 & 100 & $\mathrm{HS}$ & 4.3 & 80 & $\mathrm{HS}$ & 4.6 & 100 & $\mathrm{HS}$ & 4.2 & 60 \\
TVu 12349 & $\mathrm{MR}$ & 3.2 & 60 & $\mathrm{MR}$ & 2.8 & 60 & $\mathrm{~S}$ & 3.9 & 80 & $\mathrm{R}$ & 1.9 & 40 \\
CP-VAR8 & $\mathrm{S}$ & 4.4 & 80 & $\mathrm{~S}$ & 4.0 & 60 & $\mathrm{HR}$ & 1.2 & 0 & $\mathrm{HR}$ & 1.0 & 0 \\
IT83D-442 & $\mathrm{MR}$ & 3.2 & 50 & $\mathrm{MR}$ & 2.8 & 40 & $\mathrm{~S}$ & 3.9 & 60 & $\mathrm{HR}$ & 1.0 & 0 \\
IT90K-284-2 & $\mathrm{HR}$ & 1.0 & 0 & $\mathrm{HR}$ & 1.0 & 0 & $\mathrm{~S}$ & 3.5 & 40 & $\mathrm{HR}$ & 1.0 & 0 \\
TVu 66 & $\mathrm{S}$ & 4.2 & 60 & $\mathrm{~S}$ & 3.8 & 60 & $\mathrm{HS}$ & 4.6 & 100 & $\mathrm{~S}$ & 4.2 & 60 \\
TVu 11426 & $\mathrm{MR}$ & 3.2 & 40 & $\mathrm{R}$ & 3.6 & 20 & $\mathrm{MR}$ & 3.0 & 70 & $\mathrm{HR}$ & 1.0 & 0 \\
TVu 1190 & $\mathrm{S}$ & 3.8 & 100 & $\mathrm{R}$ & 2.2 & 20 & $\mathrm{MR}$ & 3.2 & 80 & $\mathrm{HR}$ & 1.0 & 0 \\
TVu 13686 & $\mathrm{S}$ & 4.2 & 100 & $\mathrm{MR}$ & 3.2 & 40 & $\mathrm{~S}$ & 4.2 & 100 & $\mathrm{MR}$ & 2.8 & 40 \\
\hline
\end{tabular}

Key: RES = Response to infection; SEV = Disease severity; INC = Incidence of infection (\%); HR = highly resistant; R = resistant; $\mathrm{MR}=$ moderately resistant; $\mathrm{S}=$ susceptible; $\mathrm{HS}=$ highly susceptible. $\mathrm{BCMV}-\mathrm{BIC}=$ Bean common mosaic virus - blackeye cowpea strain; CABMV = Cowpea aphid - borne mosaic virus; $\mathrm{CMeV}=$ cowpea mottle virus; SBMV = Southern bean mosaic virus.

Table 2. Comparison of the number of days after planting to $50 \%$ flowering of cowpea lines infected with four seed transmitted viruses.

\begin{tabular}{llllll}
\hline Lines & BCMV-BIC & CABMV & CMeV & SBMV & CONTROL \\
\hline Ife Brown & $46.3^{\mathrm{a}}$ & $45.6^{\mathrm{a}}$ & $45.5^{\mathrm{a}}$ & $46.3^{\mathrm{a}}$ & $45.7^{\mathrm{a}}$ \\
IT82D-716 & $36.4^{\mathrm{a}}$ & $36.4^{\mathrm{a}}$ & $36.1^{\mathrm{a}}$ & $36.4^{\mathrm{a}}$ & $36.2^{\mathrm{a}}$ \\
IT82D-889 & $34.4^{\mathrm{a}}$ & $34.5^{\mathrm{a}}$ & $34.6^{\mathrm{a}}$ & $34.0^{\mathrm{a}}$ & $34.4^{\mathrm{a}}$ \\
IT84S-2246-4 & $41.9^{\mathrm{a}}$ & $42.1^{\mathrm{a}}$ & $41.4^{\mathrm{a}}$ & $41.6^{\mathrm{a}}$ & $42.2^{\mathrm{a}}$ \\
IT86D-371 & $35.8^{\mathrm{a}}$ & $360^{\mathrm{a}}$ & $35.6^{\mathrm{a}}$ & $36.0^{\mathrm{a}}$ & $35.5^{\mathrm{a}}$ \\
IT86D-880 & $35.1^{\mathrm{a}}$ & $35.5^{\mathrm{a}}$ & $34.9^{\mathrm{a}}$ & $35.4^{\mathrm{a}}$ & $34.0^{\mathrm{a}}$ \\
IT96D-774 & $36.0^{\mathrm{a}}$ & $36.1^{\mathrm{a}}$ & $35.8^{\mathrm{a}}$ & $36.4^{\mathrm{a}}$ & $35.5^{\mathrm{a}}$ \\
TVu 12349 & $48.1^{\mathrm{a}}$ & $47.6^{\mathrm{a}}$ & $48.0^{\mathrm{a}}$ & $46.6^{\mathrm{a}}$ & $47.2^{\mathrm{a}}$ \\
CP-VAR8 & $40.1^{\mathrm{a}}$ & $40.6^{\mathrm{a}}$ & $41.0^{\mathrm{a}}$ & $40.6^{\mathrm{a}}$ & $39.9^{\mathrm{a}}$ \\
IT83D-442 & $36.5^{\mathrm{a}}$ & $36.3^{\mathrm{a}}$ & $34.6^{\mathrm{a}}$ & $34.0^{\mathrm{a}}$ & $34.4^{\mathrm{a}}$ \\
IT90K-284-2 & $34.4^{\mathrm{a}}$ & $35.0^{\mathrm{a}}$ & $35.0^{\mathrm{a}}$ & $34.6^{\mathrm{a}}$ & $342^{\mathrm{a}}$ \\
TVu 66 & $48.3^{\mathrm{a}}$ & $49.1^{\mathrm{a}}$ & $48.0^{\mathrm{a}}$ & $49.0^{\mathrm{a}}$ & $47.0^{\mathrm{a}}$ \\
TVu 11426 & $35.8^{\mathrm{a}}$ & $36.0^{\mathrm{a}}$ & $35.9^{\mathrm{a}}$ & $35.8^{\mathrm{a}}$ & $35.1^{\mathrm{a}}$ \\
TVu 1190 & $45.5^{\mathrm{a}}$ & $45.8^{\mathrm{a}}$ & $46.4^{\mathrm{a}}$ & $45.9^{\mathrm{a}}$ & $46.1^{\mathrm{a}}$ \\
TVu 13686 & $51.7^{\mathrm{a}}$ & $51.2^{\mathrm{a}}$ & $50.8^{\mathrm{a}}$ & $49.8^{\mathrm{a}}$ & $50.3^{\mathrm{a}}$ \\
\hline
\end{tabular}

Key: BCMV-BIC = Bean common mosaic virus - blackeye cowpea strain; CABMV = Cowpea aphid - borne mosaic virus; $\mathrm{CMeV}=$ cowpea mottle virus; $\mathrm{SBMV}=$ Southern bean mosaic virus; ${ }^{\mathrm{a}}$ Number with the same letters across the rows are not significantly different at $5 \%$ probability (LSMeans)

Table 3. Comparison of the number of days from planting to maturity of cowpea lines with four seed

\begin{tabular}{|c|c|c|c|c|c|}
\hline Lines & BCMV-BIC & CABMV & CMeV & SBMV & CONTROI \\
\hline Ife Brown & $76.0^{\mathrm{a}}$ & $74.9^{a}$ & $75.7^{a}$ & $76.1^{\mathrm{a}}$ & $76.1^{\mathrm{a}}$ \\
\hline IT82D-716 & $66.2^{a}$ & $66.5^{\mathrm{a}}$ & $66.1^{\mathrm{a}}$ & $66.6^{\mathrm{a}}$ & $66.7^{a}$ \\
\hline IT82D-889 & $64.6^{a}$ & $64.9^{a}$ & $64.6^{\mathrm{a}}$ & $64.4^{a}$ & $64.8^{a}$ \\
\hline IT84S-2246-4 & $70.1^{\mathrm{a}}$ & $69.8^{\mathrm{a}}$ & $70.4^{\mathrm{a}}$ & $71.5^{\mathrm{a}}$ & $72.3^{a}$ \\
\hline IT86D-371 & $65.8^{a}$ & $65.7^{a}$ & $65.9^{\mathrm{a}}$ & $66.6^{\mathrm{a}}$ & $65.9^{a}$ \\
\hline IT86D-880 & $65.9^{a}$ & $65.6^{a}$ & $65.4^{a}$ & $64.4^{a}$ & $65.2^{a}$ \\
\hline IT96D-774 & $67.2^{\mathrm{a}}$ & $66.1^{\mathrm{a}}$ & $66.6^{\mathrm{a}}$ & $66.8^{\mathrm{a}}$ & $66.4^{a}$ \\
\hline TVu 12349 & $84.2^{a}$ & $83.2^{\mathrm{a}}$ & $82.5^{a}$ & $82.2^{a}$ & $83.4^{a}$ \\
\hline CP-VAR8 & $69.9^{a}$ & $70.5^{\mathrm{a}}$ & $70.9^{a}$ & $70.7^{\mathrm{a}}$ & $70.4^{\mathrm{a}}$ \\
\hline IT83D-442 & $70.7^{\mathrm{a}}$ & $72.7^{\mathrm{a}}$ & $69.7^{a}$ & $69.3^{a}$ & $70.4^{a}$ \\
\hline IT90K-284-2 & $65.1^{\mathrm{a}}$ & $65.3^{a}$ & $65.3^{\mathrm{a}}$ & $65.3^{a}$ & $65.0^{a}$ \\
\hline TI... & ni $\cap a$ & $n \rightarrow>a$ & $\operatorname{nn} n a$ & 0119 & nก o a \\
\hline
\end{tabular}

RESPONSE OF COWPEA LINES TO INOCULATION

\begin{tabular}{cccccc} 
TVu 1190 & $80.3^{a}$ & $79.9^{a}$ & $81.7^{a}$ & 80.6 & $80.8^{a}$ \\
TVu 13686 & $95.4^{\mathrm{a}}$ & $92.0^{\mathrm{a}}$ & $94.4^{\mathrm{a}}$ & $94.5^{\mathrm{a}}$ & $95.3^{\mathrm{a}}$ \\
\hline
\end{tabular}

Key: $\mathrm{BCMV}-\mathrm{BIC}=$ Bean common mosaic virus - blackeye cowpea strain; CABMV = Cowpea aphid - borne mosaic virus; $\mathrm{CMeV}=$ cowpea mottle virus; $\mathrm{SBMV}=$ Southern bean mosaic virus; ${ }^{2}$ Number with the same letters across the rows are not significantly different at $5 \%$ probability (LSMeans) 
Table 4. Comparison of the mean mature plant height of cowpea lines infected with four seed transmitted

\begin{tabular}{llllll}
\hline Lines & BCMV-BIC & CABMV & CMeV & SBMV & CONTROL \\
\hline Ife Brown & $38.9^{\mathrm{c}}$ & $98.7^{\mathrm{a}}$ & $73.2^{\mathrm{b}}$ & $73.7^{\mathrm{b}}$ & $109.6^{\mathrm{a}}$ \\
IT82D-716 & $46.7^{\mathrm{b}}$ & $55.2^{\mathrm{a}}$ & $44.9^{\mathrm{b}}$ & $54.4^{\mathrm{a}}$ & $60.7^{\mathrm{a}}$ \\
IT82D-889 & $53.8^{\mathrm{a}}$ & $59.4^{\mathrm{a}}$ & $52.0^{\mathrm{a}}$ & $56.9^{\mathrm{a}}$ & $59.1^{\mathrm{a}}$ \\
IT84S-2246-4 & $46.8^{\mathrm{bc}}$ & $74.3^{\mathrm{a}}$ & $51.2^{\mathrm{b}}$ & $65.0^{\mathrm{ab}}$ & $77.6^{\mathrm{a}}$ \\
IT86D-371 & $67.2^{\mathrm{b}}$ & $81.6^{\mathrm{a}}$ & $70.9^{\mathrm{ab}}$ & $68.1^{\mathrm{ab}}$ & $77.6^{\mathrm{a}}$ \\
IT86D-880 & $115.6^{\mathrm{a}}$ & $118.3^{\mathrm{a}}$ & $109.3^{\mathrm{a}}$ & $106.3^{\mathrm{a}}$ & $116.3^{\mathrm{a}}$ \\
IT96D-774 & $47.9^{\mathrm{b}}$ & $70.6^{\mathrm{a}}$ & $48.3^{\mathrm{b}}$ & $74.0^{\mathrm{a}}$ & $74.8^{\mathrm{a}}$ \\
TVu 12349 $_{\text {CP-VAR8 }}$ & $189.8^{\mathrm{c}}$ & $230.7^{\mathrm{a}}$ & $211.2^{\mathrm{b}}$ & $227.2^{\mathrm{a}}$ & $238.4^{\mathrm{a}}$ \\
IT83D-442 & $61.7^{\mathrm{b}}$ & $74.3^{\mathrm{ab}}$ & $78.9^{\mathrm{a}}$ & $77.5^{\mathrm{a}}$ & $76.8^{\mathrm{a}}$ \\
IT90K-284-2 & $135.3^{\mathrm{a}}$ & $139.6^{\mathrm{a}}$ & $191.6^{\mathrm{c}}$ & $225.6^{\mathrm{b}}$ & $277.9^{\mathrm{a}}$ \\
TVu 66 & $55.8^{\mathrm{a}}$ & $56.3^{\mathrm{a}}$ & $45.4^{\mathrm{a}}$ & $56.2^{\mathrm{a}}$ & $56.4^{\mathrm{a}}$ \\
TVu 11426 $_{\text {TVu 1190 }}$ & $50.5^{\mathrm{bc}}$ & $57.6^{\mathrm{b}}$ & $48.1^{\mathrm{c}}$ & $64.9^{\mathrm{a}}$ & $70.8^{\mathrm{a}}$ \\
TVu 13686 & $107.4^{\mathrm{b}}$ & $132.8^{\mathrm{a}}$ & $91.6^{\mathrm{c}}$ & $129.2^{\mathrm{a}}$ & $137.0^{\mathrm{a}}$ \\
\hline
\end{tabular}

Key: BCMV-BIC = Bean common mosaic virus - blackeye cowpea strain; CABMV = Cowpea aphid - borne mosaic virus; $\mathrm{CMeV}=$ cowpea mottle virus; $\mathrm{SBMV}=$ Southern bean mosaic virus; ${ }^{\mathrm{a}}$ Number with the same letters across the rows are not significantly different at $5 \%$ probability (LSMeans)

Table 5. Comparison of the number of pods per plant of cowpea lines infected with four seed transmitted viruses

\begin{tabular}{llllll}
\hline Lines & BCMV-BIC & CABMV & CMeV & SBMV & CONTROL \\
\hline Ife Brown & $8.4^{\mathrm{c}}$ & $18.1^{\mathrm{b}}$ & $16.1^{\mathrm{b}}$ & $18.9^{\mathrm{b}}$ & $27.1^{\mathrm{a}}$ \\
IT82D-716 & $14.6^{\mathrm{b}}$ & $16.3^{\mathrm{b}}$ & $9.8^{\mathrm{c}}$ & $16.1^{\mathrm{b}}$ & $21.8^{\mathrm{a}}$ \\
IT82D-889 & $17.4^{\mathrm{ab}}$ & $18.0^{\mathrm{ab}}$ & $16.2^{\mathrm{b}}$ & $15.5^{\mathrm{b}}$ & $19.4^{\mathrm{a}}$ \\
IT84S-2246-4 & $16.8^{\mathrm{c}}$ & $30.4^{\mathrm{b}}$ & $17.3^{\mathrm{c}}$ & $31.8^{\mathrm{b}}$ & $40.7^{\mathrm{a}}$ \\
IT86D-371 & $11.2^{\mathrm{b}}$ & $14.4^{\mathrm{a}}$ & $10.4^{\mathrm{b}}$ & $12.9^{\mathrm{ab}}$ & $14.7^{\mathrm{a}}$ \\
IT86D-880 & $14.7^{\mathrm{a}}$ & $14.4^{\mathrm{a}}$ & $12.4^{\mathrm{b}}$ & $15.3^{\mathrm{a}}$ & $15.9^{\mathrm{a}}$ \\
IT96D-774 & $8.6^{\mathrm{a}}$ & $15.5^{\mathrm{bc}}$ & $9.0^{\mathrm{d}}$ & $13.6^{\mathrm{c}}$ & $19.7^{\mathrm{a}}$ \\
TVu 12349 & $13.2^{\mathrm{b}}$ & $15.6^{\mathrm{b}}$ & $15.6^{\mathrm{b}}$ & $18.9^{\mathrm{a}}$ & $18.9^{\mathrm{a}}$ \\
CP-VAR8 & $18.9^{\mathrm{b}}$ & $24.1^{\mathrm{a}}$ & $25.0^{\mathrm{a}}$ & $24.6^{\mathrm{a}}$ & $24.5^{\mathrm{a}}$ \\
IT83D-442 & $15.9^{\mathrm{d}}$ & $19.5^{\mathrm{c}}$ & $16.3^{\mathrm{c}}$ & $22.0^{\mathrm{bc}}$ & $25.8^{\mathrm{a}}$ \\
IT90K-284-2 & $20.1^{\mathrm{a}}$ & $19.6^{\mathrm{a}}$ & $13.8^{\mathrm{b}}$ & $20.9^{\mathrm{a}}$ & $21.0^{\mathrm{a}}$ \\
TVu 66 & $9.6^{\mathrm{c}}$ & $18.9^{\mathrm{b}}$ & $11.0^{\mathrm{c}}$ & $19.7^{\mathrm{b}}$ & $25.7^{\mathrm{a}}$ \\
TVu 11426 & $16.0^{\mathrm{a}}$ & $16.0^{\mathrm{a}}$ & $12.8^{\mathrm{b}}$ & $16.5^{\mathrm{a}}$ & $16.9^{\mathrm{a}}$ \\
TVu 1190 & $7.3^{\mathrm{d}}$ & $15.0^{\mathrm{b}}$ & $11.6^{\mathrm{c}}$ & $19.7^{\mathrm{a}}$ & $21.7^{\mathrm{a}}$ \\
TVu 13686 & $8.7^{\mathrm{c}}$ & $15.8^{\mathrm{b}}$ & $10.5^{\mathrm{c}}$ & $17.4^{\mathrm{ab}}$ & $19.2^{\mathrm{a}}$ \\
\hline
\end{tabular}

Key: BCMV-BIC = Bean common mosaic virus - blackeye cowpea strain; CABMV = Cowpea aphid - borne mosaic virus; $\mathrm{CMeV}=$ cowpea mottle virus; $\mathrm{SBMV}=$ Southern bean mosaic virus; ${ }^{a}$ Number with the same letters across the rows are not significantly different at $5 \%$ probability (LSMeans)

Table 6. Comparison of the number of seeds per pod of cowpea lines infected with four seed transmitted

\begin{tabular}{|c|c|c|c|c|c|}
\hline Lines & BCMV-BIC & CABMV & CMeV & SBMV & CONTROL \\
\hline Ife Brown & $5.7^{c}$ & $8.6^{b}$ & $8.5^{b}$ & $8.8^{b}$ & $10.5^{\mathrm{a}}$ \\
\hline IT82D-716 & $6.5^{\mathrm{b}}$ & $7.9^{a}$ & $6.2^{b}$ & $7.9^{a}$ & $8.6^{a}$ \\
\hline IT82D-889 & $12.6^{b}$ & $12.7^{b}$ & $12.6^{b}$ & $14.2^{\mathrm{a}}$ & $14.3^{a}$ \\
\hline IT84S-2246-4 & $8.1^{a b}$ & $8.5^{\mathrm{ab}}$ & $7.4^{\mathrm{b}}$ & $8.0^{\mathrm{ab}}$ & $9.4^{a}$ \\
\hline IT86D-371 & $9.4^{\mathrm{ab}}$ & $9.2^{b}$ & $9.8^{a b}$ & $10.3^{a b}$ & $10.7^{a}$ \\
\hline IT86D-880 & $11.1^{\mathrm{ab}}$ & $11.9^{a}$ & $10.4^{\mathrm{b}}$ & $11.8^{a}$ & $12.0^{a}$ \\
\hline IT96D-774 & $7.3^{\mathrm{bc}}$ & $7.7^{\mathrm{b}}$ & $6.5^{\mathrm{c}}$ & $8.6^{\mathrm{b}}$ & $10.1^{a}$ \\
\hline TVu 12349 & $13.3^{a}$ & $13.2^{a}$ & $13.9^{a}$ & $13.4^{\mathrm{a}}$ & $14.6^{a}$ \\
\hline CP-VAR8 & $10.2^{c}$ & $12.5^{\mathrm{b}}$ & $13.1^{\mathrm{a}}$ & $12.9^{\mathrm{ab}}$ & $13.7^{\mathrm{a}}$ \\
\hline 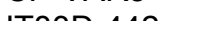 & 112 a & $\ln n$ a & $\ln n a$ & $\operatorname{an} \rightarrow a$ & $a n-a$ \\
\hline & & \multicolumn{4}{|c|}{ M. A. ITTAH. I. FAWOLE. S. A. SHOYINKA AND J. D'A. HUGHES } \\
\hline TVu 66 & $8.0^{\mathrm{C}}$ & $10.7^{\mathrm{b}}$ & $9.6^{\mathrm{b}}$ & $11.0^{\mathrm{b}}$ & $12.4^{\mathrm{a}}$ \\
\hline TVu 11426 & $15.2^{\mathrm{ab}}$ & $14.7^{\mathrm{ab}}$ & $13.9^{\mathrm{bc}}$ & $15.5^{\mathrm{ab}}$ & $16.0^{\mathrm{a}}$ \\
\hline TVu 1190 & $10.0^{\mathrm{c}}$ & $11.6^{\mathrm{bc}}$ & $11.4^{\mathrm{bc}}$ & $13.6^{\mathrm{ab}}$ & $14.6^{\mathrm{a}}$ \\
\hline TVu 13686 & $12.3^{\mathrm{c}}$ & $13.8^{\mathrm{ab}}$ & $12.8^{\mathrm{bc}}$ & $13.8^{\mathrm{a}}$ & $14.7^{\mathrm{a}}$ \\
\hline
\end{tabular}

22

Key: BCMV-BIC = Bean common mosaic virus - blackeye cowpea strain; CABMV = Cowpea aphid - borne mosaic virus; $\mathrm{CMeV}=$ cowpea mottle virus; $\mathrm{SBMV}=$ Southern bean mosaic virus; ${ }^{a}$ Number with the same letters across the rows are not significantly different at $5 \%$ probability (LSMeans) 
Table 7. Comparison of seed yield $\left(\mathrm{Kg} \mathrm{Ha}^{-1}\right)$ of cowpea lines following infection of four seed transmitted viruses

\begin{tabular}{llllll}
\hline Lines & BCMV-BIC & CABMV & CMeV & SBMV & CONTROL \\
\hline Ife Brown & $245.5^{\mathrm{c}}$ & $260.6^{\mathrm{c}}$ & $224.8^{\mathrm{c}}$ & $721.6^{\mathrm{b}}$ & $1058.4^{\mathrm{a}}$ \\
IT82D-716 & $189.9^{\mathrm{b}}$ & $177.4^{\mathrm{b}}$ & $160.0^{\mathrm{b}}$ & $288.5^{\mathrm{b}}$ & $892.5^{\mathrm{a}}$ \\
IT82D-889 & $630.7^{\mathrm{b}}$ & $871.1^{\mathrm{a}}$ & $280.3^{\mathrm{c}}$ & $835.0^{\mathrm{a}}$ & $932.1^{\mathrm{a}}$ \\
IT84S-2246-4 & $176.6^{\mathrm{b}}$ & $176.8^{\mathrm{b}}$ & $158.0^{\mathrm{b}}$ & $295.6^{\mathrm{b}}$ & $793.9^{\mathrm{a}}$ \\
IT86D-371 & $119.7^{\mathrm{c}}$ & $126.7^{\mathrm{c}}$ & $103.0^{\mathrm{c}}$ & $426.0^{\mathrm{b}}$ & $974.7^{\mathrm{a}}$ \\
IT86D-880 & $937.1^{\mathrm{a}}$ & $1033.2^{\mathrm{a}}$ & $95.5^{\mathrm{b}}$ & $1056.9^{\mathrm{a}}$ & $1055.2^{\mathrm{a}}$ \\
IT96D-774 & $151.6^{\mathrm{b}}$ & $184.1^{\mathrm{b}}$ & $159.6^{\mathrm{b}}$ & $309.0^{\mathrm{b}}$ & $1003.4^{\mathrm{a}}$ \\
TVu 12349 & $269.7^{\mathrm{c}}$ & $568.6^{\mathrm{b}}$ & $264.3^{\mathrm{c}}$ & $741.5^{\mathrm{b}}$ & $822.5^{\mathrm{a}}$ \\
CP-VAR8 & $448.3^{\mathrm{b}}$ & $541.0^{\mathrm{b}}$ & $1205.9^{\mathrm{a}}$ & $1087.3^{\mathrm{a}}$ & $1198.4^{\mathrm{a}}$ \\
IT83D-442 & $342.2^{\mathrm{cd}}$ & $210.3^{\mathrm{d}}$ & $177.0^{\mathrm{d}}$ & $482.0^{\mathrm{bc}}$ & $1272.2^{\mathrm{a}}$ \\
IT90K-284-2 & $1103.9^{\mathrm{a}}$ & $1099.4^{\mathrm{a}}$ & $552.6^{\mathrm{b}}$ & $1123.7^{\mathrm{a}}$ & $1103.5^{\mathrm{a}}$ \\
TVu 66 & $199.5^{\mathrm{c}}$ & $561.7^{\mathrm{a}}$ & $115.5^{\mathrm{c}}$ & $288.1^{\mathrm{b}}$ & $641.0^{\mathrm{a}}$ \\
TVu 11426 & $1627.7^{\mathrm{a}}$ & $1624.8^{\mathrm{a}}$ & $628.5^{\mathrm{b}}$ & $1737.0^{\mathrm{a}}$ & $1816.9^{\mathrm{a}}$ \\
TVu 1190 & $241.5^{\mathrm{cd}}$ & $390.5^{\mathrm{c}}$ & $210.6^{\mathrm{d}}$ & $921.8^{\mathrm{b}}$ & $1851.1^{\mathrm{a}}$ \\
TVu 13686 & $148.5^{\mathrm{b}}$ & $435.1^{\mathrm{a}}$ & $217.2^{\mathrm{b}}$ & $474.9^{\mathrm{a}}$ & $545.4^{\mathrm{a}}$ \\
\hline
\end{tabular}

Key: BCMV-BIC = Bean common mosaic virus - blackeye cowpea strain; CABMV = Cowpea aphid - borne mosaic virus; $\mathrm{CMeV}=$ cowpea mottle virus; $\mathrm{SBMV}=$ Southern bean mosaic virus; ${ }^{a}$ Number with the same letters across the rows are not significantly different at $5 \%$ probability (LSMeans)

\section{DISCUSSION}

This study has compared the responses of cowpea cultivars to very destructive pathogens of the plant namely; Bean common mosaic virus genus Potyvirus - blackeye cowpea strain (BCMV - BIC), Cowpea aphid-borne mosaic virus genus Potyvirus (CABMV), Cowpea mottle virus genus Carmovirus $(\mathrm{CMeV})$ and Southern bean mosaic virus genus Sobemovirus (SBMV). The symptoms expressed by the lines were similar to those reported by Ittah (2004); both the severity and incidences of infection were low in the highly resistant and resistant genotypes, and high in the susceptible and highly susceptible lines. But the incidence of BCMV - BIC and CMeV on TVu 13686, TVu 66 and IT82D-889 lines were higher in the field than in the screenhouse probably due to the differences in ambient conditions in the two environments. From PAS - ELISA study of symptomless plots, one in each of the five randomly selected plant samples, IT86D-880 infected with BCMV - BIC and CP-VAR8 infected with $\mathrm{CMeV}$ had infection. This may be due to latent infection, or to mutation in the cowpea lines or strain of virus leading to breakdown of resistance, or due to seed - lot bearing similar seeds from other varieties. The last option is the most probable; therefore, utmost care should be exercised in the handling of seeds to avoid contamination of seed - lots.

The seed - borne viruses induced very severe infection symptoms in some cowpea genotypes, whereas, in others the effect varied from moderate to no infection at all. With PAS - ELISA analysis, genotypes with no infection are highly resistant to the virus whereas the genotypes with very severe infections are highly susceptible. As such, IT90K-284-2 and IT86D-880 were highly resistant to BCMV - BIC, these lines and IT82D889 were highly resistant to CABMV and SBMV. IITA (1997) had reported IT90K-284-2 was resistant to CABMV, SBMV and BCMV - BIC infection syndrome. The varieties IT82D-889 and IT86D-880 are hereby recommended to the listing. CP-VAR8 was the only variety highly resistant to infections caused $\mathrm{CMeV}$, it is also recommended for breeding purposes. The resistant lines (CP-VAR8, IT90K-284-2, IT82D-889 and IT86D880 ) have potentials to be useful in breeding programme to develop elite cowpea lines, in particular CP-VAR8, because cowpea lines resistant to $\mathrm{CMeV}$ have not been found (Allen et al., 1982; Ogundiwin 2000).

$\mathrm{BCMV}-\mathrm{BIC}$ and $\mathrm{CMeV}$ were more virulent pathogens than CABMV and SBMV because they infected more cowpea lines, and CABMV infected more cowpea genotypes than SBMV. BCMV - BIC and $\mathrm{CMeV}$ were so destructive that suggestion is hereby made that, once either or both of these viruses are observed in farmers' fields, very rigorous management strategies must be adopted immediately to destroy them for the future of the crop; such strategies as roguing of infected and volunteer plants, destruction of vectors or most importantly, cultivation of resistant cultivars in the endemic area. CMeV and BCMV - BIC significantly reduced the plant height, number of pods per plant and seed yield than CABMV and SBMV $(p<0.05)$. BCMV $B I C$ reduced the plant height, number of pods per plant and yield per hectare than $\mathrm{CMeV}(p<0.05)$. Earlier studies had reported similar reductions in yield (Kaiser and Mossahebi, 1975; Singh and Singh, 1985), foliar weight (Anderson et al., 1996) and other traits, and

\section{RESPONSE OF COWPEA LINES TO INOCULATION}

to $50 \%$ flowering and the number of days from planting to maturity in any of the cowpea lines.

None of the 15 cowpea genotypes was highly resistant to all the four seed-borne viruses but TVu 11426, IT86D-371 and IT86D-880 were moderately resistant (tolerant) to $\mathrm{BCMV}-\mathrm{BIC}$ and $\mathrm{CMeV}$ and highly resistant to SBMV. IT82D-889, IT90K-284-2 and TVu 12349 were resistant to BCMV - BIC, CABMV and SBMV. Resistance and moderate resistance to virus infection observed in some genotypes imply that the viruses multiply within the host plant but do not severely change the agronomic and yield component traits (Walkey, 1985), those lines are tolerant. Similar to the highly resistant genotypes, the tolerant genotypes can also be used in programmes to develop improved cowpea lines (Allen et al., 1982), which will provide a 
better virus disease management strategy. Combining resistance and tolerance genes from several genotypes means that protection is introduced from multiple sources of identified resistance and that would be a more effective strategy.

\section{REFERENCES}

Allen, D. J., G. Thottappilly and H. W. Rossel., 1982. Cowpea mottle virus: field resistance and seed transmission in virus - tolerant cowpea. Annals of Applied Biology, 100: 331 - 336.

Anderson, E. J., A. S. Kline, T. E. Morelock and R. W. McNew., 1996. Tolerance to Blackeye cowpea mosaic Potyvirus not correlated with decreased virus accumulation or protection from cowpea stunt disease. Plant Disease 80: 874 - 852.

Bashir M. and R. O. Hampton., 1993. Natural occurrence of five seed-borne cowpea viruses in Pakistan. Plant Disease 77: 948- 951

Bennett, C. W., 1969. Seed transmission of plant viruses. Advances in Virus Research 14: 221 261.

Boxtel, J., B. B. Singh, G. Thottappilly and A. J. Maule., 2000. Resistance of cowpea (Vigna unguiculata (L) Walp) breeding genotypes to blackeye cowpea mosaic and cowpea aphid-borne mosaic potyvirus isolates under experimental conditions. Zeitschrift für Pflanzenkrankheiten und Pflanzenschutz 107: 197 - 204.

Coulibaly, O. and J. Lowenberg - DeBoer., 2002. The economics of cowpea in West Africa. In: Challenges and Opportunities for Enhancing Sustainable Cowpea Production pp 351 - 366. Proceedings of the World Cowpea Conference III held at the International Institute of Tropical Agriculture (IITA), Ibadan, Nigeria, 4 - 8 September, 200. IITA, Ibadan, Nigeria.

Culver, J. N. and M. S. Padmanabhan., 2007. Virus induced disease: altering host physiology one interaction at a time. Annual Review of Phytopathology 45: 221 - 243

De Wolf, E. D. and S. A. Isard., 2007. Disease cycle approach to plant disease prediction. Annual Review of Phytopathology 45: 203 - 220.

FAO (Food and Agriculture Organisation)., 2000. FAO statistics of food and agriculture

Gomez, K. A. and A. A. Gomez., 1984. Statistical Procedures for Agricultural Research $2^{\text {nd }}$ Edition, John Wiley and Sons, New York 680 pp.

Hampton, R. O., G Thottappilly, and H. W. Rossel., 1997. Viral diseases of cowpea and their control by resistance-conferring genes. In: Advances in Cowpea Research. pp 159 - 175. B. B. Singh, D. R. Mohan Raj, K. E. Dashiel and L. E. N.
Jackai (eds.) International Institute of Tropical Agriculture (IITA)/Japan International Research Centre for Agricultural Sciences (JIRCAS).

Hughes, J. d'A and B. J. Thomas., 1988. The use of Protein - A sandwich ELISA as a means for quantifying serological relationships between members of the Tobamovirus group. Annals of Applied Biology 112: 117 - 126.

Hutchinson, C. M. and M. E. McGiffen Jr., 2000 Cowpea cover crop mulch for weed control in desert pepper production. HortScience 35: 196 - 198

IITA (International Institute of Tropical Agriculture, Ibadan, Nigeria)., 1997 Project 11: Cowpea-Cereals systems improvement in the dry Savannas IITA Annual Report 1997 pp 62.

Ittah, M. A., 2004. Screening cowpea (Vigna unguiculata (L) Walp) lines for infection responses to some cowpea viruses in Nigeria. Global Journal of Pure and Applied Sciences 10: 473 - 478.

Jackai, L. E. N. and C. B. Adalla., 1997. Pest management practices in cowpea: a review, In: Advances in Cowpea Research. pp 240 - 258. B. B. Singh, D. R. Mohan Raj, K. E. Dashiel and L. E. N. Jackai (eds.) International Institute of Tropical Agriculture (IITA)/Japan International Research Centre for Agricultural Sciences (JIRCAS).

Kaiser, W. J. and H. Mossahebi., 1975. Studies with cowpea aphid-borne mosaic virus and its effects on cowpea in Iran. FAO Plant Protection Bulletin 27: 27 - 30

Mali, V. R., V. P. Khalikar and D. H. Gaushal., 1983. Seed transmission of poty- and cucumber virus in cowpea in India. Indian Phytopathology 36: 343.

Mishra, S. N., J. S. Verma and S. J. B. A. Jayasekara., 1985. Breedina cowpea to suit Asian croppina svstems

24

M. A. ITTAH, I. FAW

by S. R. Singh and K. O. Rachie. John Wiley and sons, Chichester, UK

Ogundiwin, E. A., 2000. Genetic Dissection of Cowpea Mottle Viral Disease Resistance in Vigna species. Ph. D thesis submitted in the Department of Agronomy, the Faculty of Agriculture and Forestry, University of Ibadan, Nigeria. 193p.

Phatak, H. C., 1974. Seed-borne viruses: Identification and diagnoses in seed-health testing. Seed Science and Technology, 23 - 155.

Quin, F. M., 1997. Introduction. In: Advances in Cowpea Research. pp ix - xv. B. B. Singh, D. R. Mohan Raj, K. E. Dashiel and L. E. N. Jackai (eds.) International Institute of Tropical Agriculture 
(IITA)/Japan International Research Centre for Agricultural Sciences (JIRCAS).

SAS institute., 1995. SAS language and procedure: Usage. Version $6,1^{\text {st }}$ ed. SAS Inst., Cary, NC

Shoyinka S. A., G. Thottappilly, G. G. Adebayo and F. O. Anno-Nyako., 1997. Survey on cowpea virus incidence and distribution in Nigeria. International Journal of Pest Management 43: 127-132.

Singh, A. K. and A. K. Singh., 1985. Effects of cowpea mosaic virus (CPMV) and Southern bean mosaic virus (SBMV) on yield of cowpea. Tropical Grain Legume Bulletin 31: 20 - 23.

Singh, B. B. and B. R. N'tare., 1985. Development of improved cowpea lines in Africa In: Cowpea Research, Production and Utilisation pp 105 115 edited by S. R. Singh and K. O. Rachie. John Wiley and sons, Chichester, UK
Thottappilly, G., N. Q. Ng and H. W. Rossel., 1994. Screening germplasm of Vigna vexilata for resistance to cowpea mottle virus. International Journal of Tropical Plant Diseases, 12: 75 - 80.

Walkey, D. G. A., 1985. Applied Plant Virology. Chapman and Hall, London 305p.

Watt, E. E., E. A. Kweneman and J. P. P., 1985 Achievements in breeding cowpea Latin America In: Cowpea Research, Production and Utilisation pp 125 - 135 edited by S. R. Singh and K. O. Rachie. John Wiley and sons, Chichester, UK

Stace-Smith J. P. and R. I. Hamilton., 1988. Inoculum thresholds of seed borne pathogens: Viruses. Phytopathology 78: 875 - 880 .

Taiwo, M. A. and S. A. Shoyinka ., 1988. Viruses infecting cowpea in Africa with special emphasis on the potyviruses. In: Virus Disease of Plants in Africa pp 39 - 115. O. Williams, A. L. Mbiele and N. Nkouka (eds.). OAU/CTA, Nigeria,

Tarawali, S. A., B. B. Singh, S. C. Gupta, R. Tabo, F. Harris, S. Nokoe, S. Fernandez - Rivero, A. Bationa, V. M. Manyong, K. Makinde and E. C. Odion., 2002 Cowpea as a key factor for a new approach to integrated crop - livestock systems research in the dry savannas of West Africa. In: Challenges and Opportunities for Enhancing Sustainable Cowpea Production, pp 233 - 251. Proceedings of the World Cowpea Conference III held at the International Institute of Tropical Agriculture (IITA) Ibadan, Nigeria. 